\title{
Defining and Regulating Zero Hours Work: Lessons from a Liberal Market Economy'
}

\section{Lorraine Ryan'}

Researcher, Department of Work and Employment Studies, University of Limerick, Ireland

\section{Jonathan Lavelle}

Senior Lecturer, Department of Work and Employment Studies, University of Limerick, Ireland

\section{Michelle O'Sullivan}

Senior Lecturer, Department of Work and Employment Studies, University of Limerick, Ireland

\section{Juliet McMahon}

Lecturer, Department of Work and Employment Studies, University of Limerick, Ireland

\section{Caroline Murphy}

Lecturer, Department of Work and Employment Studies, University of Limerick, Ireland

I Tom Turner

Professor, Department of Work and Employment Studies, University of Limerick, Ireland

\section{Patrick Gunnigle}

Professor, Department of Work and Employment Studies, University of Limerick, Ireland

\section{Mike O'Brien}

Lecturer, Management Development Unit, University of Limerick, Ireland

\begin{abstract}
The apparent rise in precarious work has received increased attention in a number of countries in recent decades. However, studies highlight the difficulties of both defining and capturing the extent of precarious work. In this paper, we report on a study of zero hours contracts in Ireland and drawing on the varieties of capitalism framework, examine the lessons for both LMEs and CMEs. The study found that zero hours contracts, as defined by Irish legislation, were not common; however, evidence of 'If and When' contracts emerged during the course of the research. We outline our key findings showing how information garnered from qualitative research provided nuanced insights on the reality of precarious work, which was not captured in the national data set. This is important for measuring the extent of precarious work in future studies.
\end{abstract}

\section{KEYWORDS}

Atypical employment / If and when contracts / Labor market / On-call work / Precarious work / Varieties of capitalism / Zero hours contracts

\footnotetext{
${ }^{1}$ You can find this text and its DOI at https://tidsskrift.dk/njwls/index.

${ }^{2}$ Corresponding author: Dr. Lorraine Ryan, Department of Work and Employment Studies, Kemmy Business School, University of Limerick, Ireland. Email: Lorraine.t.ryan@ul.ie.
} 


\section{Introduction}

ssues around precarious work are being debated in a number of countries in recent years (Barnard 2014; McCann 2014). While difficulties with defining and measuring precarious work persist, it is broadly accepted that there is a growing cohort of workers characterized by job insecurity, short-term contracts, lack of rights at work, and often low pay (Lea 2013; Vosko 2010). Those employed in precarious jobs are at a disproportionally high risk of poverty and are at risk of detrimental psychological effects (Olsthoorn 2014). The apparent rise in precarious work has led to trade unions and other organizations calling for regulation to protect workers from the negative effects of such work in many countries. However, in order to regulate precarious work, it is important for stakeholders and policy makers to understand the intricacies of different types of employment contracts; otherwise, it may be relatively easy for employers to circumvent any regulation. It is also important not to curtail flexibility in a modern labor market. One form of precarious work that is currently receiving much academic, media and public policy attention is zero hours contracts (Adams et al. 2015; CIPD 2013). These have recently come under political and public scrutiny in a number of countries, notably Ireland, the UK, Finland, and New Zealand. Trade unions have criticized their use by employers and have sought greater protection for people working on a zero hours basis. Such contracts are typified by nonguaranteed hours of work and a lack of entitlement to rights under existing protective legislation (such as unfair dismissals and redundancy). A key difficulty remains, however, regarding definitional uncertainty of such contracts in many countries and thus their legal regulation. The term 'zero hours contracts' has become synonymous with precarious work but is often used to describe a range of different forms of work such as part-time work, casual work, low hours, and on-call work. Indeed, Adams et al. (2015:2) note that the zero hours contract label 'serves as no more than convenient shorthand for masking the explosive growth of precarious work for a highly fragmented workforce'. Consequently, quantifying the proportion of the labor market employed under zero hours contracts and regulating their use remains problematic. The lack of clarity also hinders cross-country comparisons, which are important for researchers and policy makers. What do we mean when we talk about 'zero hours contracts'?

It is useful for international comparisons of work issues to examine particular phenomena such as zero hours contracts in depth in one country. This provides novel insights, improves cross-national understanding, and facilitates comparisons of issues around such work between countries. Ireland represents an interesting case with which to examine issues around zero hours contracts, as it is considered an atypical Liberal Market Economy (LME) having a historical legacy of features more typical of Coordinated Market Economies (CME) (O'Sullivan et al. 2017). Issues around zero hours work have received increased media, public and political attention in Ireland of late and the findings from a study of zero hours contracts will have relevance for LMEs and CMEs alike. A key contribution of this article is that it highlights the nuanced differences within distinct types of atypical employment arrangements, commonly referred to as 'zero hours contracts' within Ireland. The article demonstrates how utilizing qualitative research methods in the form of interviews with informed stakeholders proved critical in identifying and understanding these differences, particularly with regard to the legal complexities of workers' status. As with some other countries (e.g., timanställningar in 
Sweden), information on the number of workers employed on zero hours contracts in Ireland is not currently sufficiently captured in the national labor force statistics. This article provides guidance on how these data should be more accurately garnered in the future while also highlighting the problems of precarious work more generally. The findings of the study are important if different forms of precarious work are to be more effectively regulated within the Irish context. It also provides insights for researchers, practitioners, and policy makers relying on cross-national comparisons, as it provides a deeper understanding of the legal complexities surrounding zero hours contracts. In fact, we find it is more appropriate to use the term zero hours work, as this encapsulates more accurately the reality of contemporary employment practices and overcomes some of the problems associated with the strict legal definition of a zero hours contract. This helps in achieving a common cross-national interpretation of terminology.

In this paper, we examine issues around zero hours work thus adding to the literature in this limited but growing research area. In doing so, it addresses the following research questions: What are the issues around defining and measuring zero hours work? What are the issues around regulating zero hours work? The paper is structured as follows. First, we examine the literature on precarious work and explore the difficulties with defining and measuring different forms of such work, in particular zero hours contracts. We also highlight the impact of zero hours work practices on workers (Burgess et al. 2013; Kalleberg 2012). Drawing on the varieties of capitalism literature, we outline why issues around zero hours work should be a concern for Nordic CME countries. Following an overview of the current regulation of zero hours contracts in Ireland, we provide an outline of the research design. We then present findings from the views of stakeholders interviewed for this study and a review of the legislation relevant to zero hours contracts. This highlights the nuanced differences between types of employment contracts and the limitations of the existing regulatory framework in addressing the full spectrum of zero hours arrangements (zero hours work). We conclude by reflecting on how the empirical findings can be generalized to other national contexts such as the Nordic countries and the insights the research offers for cross-national studies.

\section{Zero Hours Contracts: A Core Dimension of Precarious Work}

Precarious work is not a new phenomenon. It has existed in a variety of forms since the emergence of paid employment relationships. Although use of the term precarious work is becoming common at an international level, 'its definition remains vague and multifaceted' (ILO 2012). Kalleberg (2009:2) describes precarious work as 'employment that is uncertain, unpredictable and risky from the point of view of the worker'. It is also often characterized by low income, limited social benefits, and statutory entitlements (Vosko 2010). Precarious work is conceptually different from the many forms of 'nonstandard' or 'atypical' employment that have emerged across Europe since the 1970s. These terms are used to describe any form of work that deviates from the 'standard' or 'normal' full time employment contract concluded for an indefinite period. While many forms of nonstandard or atypical employment such as part-time work, fixed term contracts, and solo self-employment may indeed be precarious, this does not necessarily apply in all cases. Research on precarious employment places the focus on material and 
psychological insecurity in employment relationships (Allmendinger et al. 2013). The risk of precariousness can vary depending on the type of nonstandard employment with, for example, job insecurity a feature of temporary work and low pay associated with casual and marginal part-time work (Broughton et al. 2016). Zero hours work typically includes no guaranteed hours offered by the employer. While some zero hours workers may be high-paid or prefer to work this way, zero hours work is considered precarious because outcomes, in the main, include low pay, job insecurity, and very limited social and employment rights protection (Blanchflower et al. 2017; Broughton et al. 2016; Eurofound 2015). As Ilsøe (2016) notes in her concept of 'living hours', the length of the working week (i.e., the number of paid hours) and the scheduling of the work week as well as hourly pay are important considerations. This is particularly so for zero hours work (O'Sullivan et al. 2015). Thus, workers are affected by a lack of financial security, poor social insurance cover, poverty traps, limited prospects for education, development and promotion, and a general lack of control over their working lives. Outside of the work sphere, there are negative spillover effects of precarious work on family life, childcare issues, and inability to plan for the future (O'Sullivan et al. 2015).

\section{Measuring Zero Hours Work}

The main type of employment relationship in the EU is full-time permanent employment (Broughton et al. 2016). However, issues around precarious work have received increased attention in recent times, as many countries see the emergence of more polarized dual labor markets and a growing cohort of workers employed in precarious work (Kalleberg 2011). A number of factors can be said to have contributed to this apparent growth initially brought about by the search for flexibility and efforts to remove rigidities in many European labor markets following the economic crisis of the 1970s (Treu 1992). These include increased competition, less regulated labor markets, privatization, declining unionization, changing demographics, the impact of technology, and the Global Financial Crisis (ILO 2012). It is concerning because of the negative impact precarious work can have on workers' physical, social, and psychological well-being. The expansion of precarious employment can serve to increase social inequality, as disadvantaged labor market groups such as women, older people, or those with lower qualification levels are particularly likely to work in these jobs with lower pay and insurance entitlements (Allmendinger et al. 2013; O'Sullivan et al. 2015).

The difficulties of researching precarious work are numerous, not least is accurately measuring such work given the difficulties of definition. While characteristics of precarious work are commonly cited in the literature and the impact on workers is widely discussed, two of the biggest challenges for both researchers and policy makers are gaining reliable data on the number of workers employed in particular types of precarious employment and sufficiently regulating such work to protect workers and employers without inhibiting labor market flexibility. National data sets may not accurately capture the extent of precarious work, albeit they capture many of its' different elements such as pay and hours of work. This paper is based on a study of one particular form of precarious work, zero hours work in Ireland with a view to examining how the research findings can be generalized to other national contexts and what lessons can be learned.

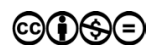


Examining issues around zero hour work involves significant complexity because of the range of terminology used, the legal complexities involved, the variety of workplace practices in operation, and challenges regarding data collection. These are the issues we address in this paper. Many questions around work and employment can be researched using national labor force survey data, often supplemented by European or World surveys on working conditions and/or social issues to improve robustness. Gathering data on the extent of zero hours contracts or zero hours work in Ireland in this way is problematic for a number of reasons. There is no national database in Ireland on types of contracts and this information is crucial when measuring zero hours work. Respondents to the national labor force survey are asked how many hours they 'usually work'. For some workers, hours may fluctuate continually from one week to another, so it is difficult to measure what hours are 'usually worked'. Others may regularly work a specific number of hours, but these are not guaranteed by the employer. Both of these may be zero hours workers. However, individual workers may themselves be unaware of the specifics of their employment contracts and the reality of people's working lives often does not match the specific terms and conditions of their contract. Thus, individuals can appear in the national labor force dataset as a regular part-time worker when the reality is they are engaged in zero hours work with the employer free to reduce or change hours of work at will. The crux of the issue for zero hours workers is whether or not the hours 'usually worked' are guaranteed.

Thus, the way in which questions are phrased in the national labor force survey (in Ireland at least) is currently insufficient to capture the details of different working contracts and the true extent of zero hours work. This means that relying on labor force statistics runs the risk of presenting skewed data, which either over or underestimate the extent of the problem of zero hours work. This was the case in the UK, for example, where the number of workers reported to be working on zero hours contracts appeared to rise significantly from 250,000 employees in 2012 according to the Office for National Statistics (ONS), to an estimate of 1 million in 2013 according to the Chartered Institute for Personnel Development (CIPD), and subsequently 697,000 according to the ONS in 2014. This prompted public debate on the regulation of zero hours work. The apparent increase was mostly due to increased public attention on zero hours contracts by the media leading to workers becoming more knowledgeable about the type of work they were actually engaged in. Indeed, the ONS (2015) noted people's lack of awareness of working on a zero hours contract as an issue in regard to their data collection. Brinkley (2013), however, notes 'whatever the hard numbers tell us, zero hours contracts have come to symbolize a wider concern that the labor market is moving towards more contingent, less secure, and more exploitative forms of employment at a time when in many areas jobs are scarce and people have little choice over taking whatever work is available'. Of course, employment issues may also be researched qualitatively, which brings different challenges in terms of validity, reliability, and generalizing results. For researchers, directly accessing those engaged in zero hours work is difficult due to the ad-hoc nature of many of these workers' employment situations and the lack of awareness of their employment situation as highlighted. Given these constraints, the study on which this paper is based set out to examine the extent of zero hours contracts in Ireland and the impact on workers. In this paper, we explore how the findings of this study can provide insights for research on precarious work in the Nordic countries. 


\section{Varieties of Capitalism and National Contexts}

There are a number of factors that influence the nature of zero hours and other forms of precarious work in different countries. A useful starting point is the varieties of capitalism (VoC) framework, which helps to understand similarities and differences across countries (cf. Hall \& Soskice 2001). The framework identifies two varieties of capitalism liberal market economies (e.g., USA, UK, and Ireland) and coordinated market economies (Germany and the Nordic countries). LMEs are broadly characterized by firms coordinating their activities according to competitive market arrangements (Hall \& Soskice 2001) and include key IR characteristics such as labor market volatility, more porous and truncated internal labor markets, lows levels of employment protection, greater labor flexibility, weak protective labor laws, low union density, and decentralized collective bargaining (Kaufmann 2011). In contrast, CMEs are characterized by firms depending more on nonmarket relationships in their dealings with other actors (Hall \& Soskice 2001) with key IR characteristics such as high levels of union density, centralized collective bargaining, well developed internal labor markets, high levels of employment protection, and less flexibility for employers in hiring and firing. Thus, according to the VoC literature, the issue of zero hours work is more likely to present itself in LMEs rather than CMEs. Indeed, there is a considerable body of literature that examines the relationship between neoliberalism and work precarity (Lea 2013; Standing 2014; Turner 2016). A key tenet of the VoC framework is institutional stability, which would suggest that the emergence of precarious work should largely only be of concern for LMEs. However, a growing body of literature has challenged this perspective, suggesting that neoliberal policies are just as likely to be evident within CMEs as they are in LMEs (Baccaro \& Howell 2011; Cerny et al. 2005; Fleckenstein \& Soohyun 2017; Heyes et al. 2012; Howell \& Givan 2011; Kinderman 2017; Streeck 2009). For example, Baccaro and Howell (2011) when analyzing a mix of capitalist countries, France, the UK, Germany, Italy, Sweden, and Ireland, found consistency in changes to their IR systems in a neoliberal direction. Heyes et al. (2012) in their analysis also pointed to the weakening of employment and social protections in both LMEs and CMEs, albeit to varying extents.

The implications of this literature would suggest that the issue of precarious work is not just a concern within LME countries, but arguably more important for CMEs, as it appears that the institutions within CMEs that should protect against precarious work may not be as resilient as expected (Fleckenstein \& Soohyun 2017; Hassel 1999, 2002; Kinderman 2017; Streeck 2009). Indeed, Ireland is an example of a country where key institutional characteristics of a CME such as high levels of trade union density and centralized collective bargaining have been significantly challenged in the last 10 years resulting in an institutional landscape that is now arguably more characteristic of an LME, thereby creating an environment for the growth of precarious work. Thus, whilst this paper is based on a study of zero hours work in an LME (Ireland), it is of interest to scholars and practitioners in CMEs such as the Nordic countries, as research shows these are not impervious to the global economic pressures driving precarious work. Finland, for example, has seen the emergence of zero hours contracts in recent times (Ollus 2016). In Denmark, a recent report pointed toward certain sectors that are under threat from economic restructuring and changes in the legal and regulatory environment opening up the possibility for a growth in precarious work (Rasmussen et al. 2016). Sweden 
and Denmark have also seen increases in temporary employment among younger workers (Berglund et al. 2017; Håkansson et al. 2012).

\section{The Irish Regulatory Framework}

A key difference between Ireland and the Nordic countries is the regulatory frameworks. While the Nordic countries are primarily characterized by high coverage of collective agreements with legal regulation having a secondary role, the decline in unionization and collective bargaining in Ireland in recent decades has meant a greater role for individual legal regulation. We draw on legal literature to explore the nuanced differences in relation to the protection afforded to workers on different types of contracts (Adams \& Deakin 2014). Key legal issues central to the examination of zero hours work are the concept of mutuality of obligation and the changing status of employees versus independent contractors. Such issues are common across a number of jurisdictions including Ireland and the UK. These are important when considering the possibilities for regulating precarious work and providing protection for workers (Adams et al. 2015; Deakin 2014). The stumbling block for those working on a zero hours basis has been the 'test for mutual obligation' and the requirement to be available for work. Broadly speaking, this test examines the extent to which the employer has contracted into an obligation to provide work and the worker has an obligation to perform that work. Zero hours work, however, is characterized by nonguaranteed hours whereby neither of these obligations apply. Contracts typically contain clauses, which state that the employer is under no obligation to provide work and the individual is under no obligation to accept. Thus, employers have successfully argued that those working on a zero hours basis are not de facto 'employees' and are outside the scope of much of the protective legislation, as there is no mutuality of obligation.

In recent years, the landscape of employment status has become more complicated with the emergence of varying forms of contracts in the workplace. The European Commission in developing a Green Paper on modernizing labor stated: 'The traditional binary distinction between "employees" and the independent "self-employed" is no longer an adequate depiction of the economic and social reality of work' (Commission of The European Communities Brussels 2006: 10). Yet, in many countries including Ireland, this binary distinction persists and remains the basis of much employment legislation. The role of legislation is particularly important in an LME such as Ireland where many sectors do not have collective bargaining coverage and so any protection for workers in those sectors is exclusively through individual employment rights enshrined in legislation. Collective bargaining is still a feature of industrial relations in Ireland and agreements covering zero hours work can be found in certain sectors (e.g., retail). However, bargaining is confined to company rather than sectoral level, and even in well-organized sectors where collective bargaining coverage exists, we still see the emergence of zero hours work. The public sector has the highest union density and collective bargaining coverage in Ireland, yet zero hours work is evident in a number of occupations in the health and education sectors for example (O'Sullivan et al. 2015). This is driven in part by funding models and increased subcontracting in these sectors. Collective bargaining in Ireland is largely voluntarist with any institutional support having eroded over the past few decades, as the economic crisis pushed Ireland further toward a typical LME (see O'Sullivan et al. 2017). 


\section{Working Time Legislation}

Legislation to address a number of issues around working time was introduced in Ireland in 1997 in response to the EU Directive (Council Directive 93/104/EC) on working time. At the time Ireland had a system of social partnership between trade unions, government, and employer organizations and the drafting of the working time legislation coincided with a new national wage agreement in 1996. The Irish Congress of Trade Unions (ICTU) demanded that employment legislation be reviewed in light of the growth of atypical work (McMahon et al. 2017). To deal with the issue of zero hours contracts, a clause was inserted in The Organisation of Working Time Act 1997 (OWTA). The clause (in Section 18 of the Act) confers an entitlement to compensation if the employer does not require the employee to work in a given week where they are required to be available. They are entitled to compensation amounting to $25 \%$ of the time they were required to be available or 15 hours pay, whichever is the lesser. Significantly, Section 18 continues to state that there must be a 'requirement' of an employee to make themselves available to work.

\footnotetext{
'This section applies to an employee whose contract of employment operates to require the employee to make himself or herself available to work for the employer in a week ... and the said requirement is not one that is held to arise by virtue only of the fact, if such be the case, of the employer having engaged the employee to do work of a casual nature for him or her'. (Extract from Section 18)
}

The problem with the clause (Section 18), however, is that by including the words 'contract of employment' and 'require' and excluding work of a 'casual nature', the Irish Courts have held that it excludes those workers who do not satisfy the test for mutual obligation. It is very easy for employers to avoid the protective provisions of the legislation by not including a contractual requirement that the employee must make themselves available for work. Thus, a 'zero hours contract' is very narrowly defined in Irish legislation and only includes contracts where mutuality exists.

\section{Methodology}

This paper draws on a number of both qualitative and quantitative methodologies. We draw on data originally collected by the authors as part of a wider report completed in 2015. This report was commissioned by the Irish government to gather data on the prevalence of zero hours contracts in the Irish economy, the manner of their use and the impact on employees. A critical component of the methodology was interviews with informed stakeholders. An interview schedule was developed by the research team based on the objectives of the study and pilot interviews were undertaken with one representative each from an employer organization and trade union. Subsequently, 32 interviews were conducted with 30 bodies [13 employer/business representative organizations, eight trade unions, five government departments/agencies, and four nongovernmental organizations (NGOs)]. Interviews with NGOs were important to ensure that voices of nonunionized workers were captured. The NGOs were representative of key worker groups typically affected by zero hours work including women, migrants and young 
people. The trade unions and NGOs were critical in providing nuanced insights into the range of issues zero hours work poses for workers. We interviewed two legal experts nominated by the Employment Law Association of Ireland who informed the discussion on the legal position of people on zero hours contracts (see O'Sullivan et al. 2015).

As part of the wider report, we also analyzed macro-level data from the Irish Quarterly National Household Survey (QNHS) from the Central Statistics Office (CSO). However, other than providing data on the number of employees who work 'constantly variable hours per week' (an inaccurate measure of zero hours work), our findings showed significant limitations in utilizing this survey. This paper is therefore primarily based on the qualitative findings. Finally, we carried out a review of current legislation The Organization of Working Time Act 1997 pertaining to the issue of employment status, as it relates to zero hours work. This brings to light the limited protections available under current legislation and the complexity of determining employment status for people on zero hours arrangements.

\section{Findings: The Reality of Zero Hours Work in Ireland}

Zero hours contracts within the meaning of the OWTA are not extensive in Ireland according to our research. Based on our interviews, very few workers in Ireland are employed under such contracts and Section 18 is rarely utilized. In fact, some trade union representatives noted that employees and trade unions would not even be aware that the section exists. Interview respondents made a number of observations, however, in relation to zero hours work and the OWTA with stakeholders revealing varying interpretations about what constitutes a zero hours contract. In general, employer representative organizations' definitions accorded to that contained in Section 18, which clearly indicates that coverage is restricted to employees employed under a contract of service and where there is an obligation on those employees to make themselves available. The interpretation of a zero hours contract by the largest employers' body, the Irish Business and Employers Confederation (IBEC), is 'a contract as it is set out in the legislation' and that a person on a zero hours contract 'has an obligation to be available'. The view of IBEC is that people on zero hours contracts are clearly employees and as such are covered by protective legislation, but such contracts 'are almost never used in Ireland'. Similarly, the Irish Hotels Federation believe that the hotel sector does 'not have zero hours contracts where someone has to be available and has to turn up but not get any work', thus also interpreting zero hours contracts solely as those that come within the ambit of Section 18 of working time legislation. The Restaurants Association of Ireland notes that it had 'never heard of a zero hours contract' until the government commissioned the study, and that it never received queries from its members about them.

Other interviewees however provided evidence of so-called 'If and When' contracts, a critical finding of this study. Essentially, 'If and When' contracts are a specific form of what is commonly referred to as 'on-call work'. They are broadly similar to zero hours contracts with the fundamental difference between the two being that individuals with a zero hours contract are contractually required to make themselves available for work with an employer, while individuals with an 'If and When' contract are not. Both types of contract involve nonguaranteed hours of work. Trade unions and the four NGOs were highly critical of 'If and When' contracts, considering them to be 
precarious jobs, which transfer the risk of business onto employees. The Irish National Organization for the Unemployed commented that people 'are taking a leap of faith' taking a job with 'If and When' hours; the largest general union in Ireland, the Services Industrial Professional and Technical Union (SIPTU) viewed them as 'exploitative' and the National Women's Council of Ireland (NWCI) considered them 'the worst of all worlds'. The Migrant Rights Centre of Ireland labelled them 'dead end hours in dead end jobs' and the ICTU stated that they have become a normalized 'business school model of running a business, it's just-in-time for workers'. In the view of trade unions and NGOs, the majority of individuals accept 'If and When' contracts because of a lack of alternatives and that there are significant negative economic and social consequences arising from their prevalence. Thus, worker representative bodies generally use definitions of zero hours work, which are broader in scope and they do not necessarily make the distinction between someone who is required to be available for work and someone who is not. The ICTU, for instance, refuse to use the term zero hours contract and instead refer to zero hours practices, which they describe as involving not knowing from week to week how many hours someone is going to work, not knowing when hours will be scheduled, and being sent home from work. These varying perspectives of stakeholders raise a critical issue that reflects the problematic nature of defining zero hours work in the Irish context.

Legal experts interviewed noted that 'If and When' workers are unlikely to be deemed employees (due to the absence of mutuality) and this raises questions about the extent to which they are covered by employment law. We also find evidence of hybrid contracts where employees have some guaranteed minimum hours and additional hours are offered on an 'If and When' basis. These were found to be prevalent in sectors such as retail and accommodation and food and samples of clauses found in such contracts are as follows:

\footnotetext{
Contract Example 1 - If and When Contract

'Your start and finish times will be explained to you by your Line Manager or will be in accordance with the rota displayed at your Place of Work. The Company reserves the right to change your normal hours of work, start and finish times at its discretion so as to meet its business needs and/or improve operational efficiency'.

Contract Example 2 - Hybrid If and When Contract

'Your minimum hours of work are 15. You are employed on a flexible hours basis and your hours can be changed to suit business requirements and needs at any time in the future. You are asked to take particular note of this requirement. You are required to work Sundays/Public Holidays as part of your working week'.
}

Source: O’Sullivan et al. 2015

Notwithstanding the differences of opinion between the stakeholders in Ireland as to what constitutes a zero hours contract, we find that there is a wider range of zero hours type practices and contracts operational than governed by the OWTA. IBEC noted that there have been very few cases taken by employees against employers under Section 18 of the Act, which, they suggest, indicates there are few problems arising from zero hours contracts and that they are not the precarious employment some would view them to be. In contrast, trade unions argue that the lack of employment cases taken under Section 18 is because people on 'If and When' contracts are excluded from its scope. 
Table I Terminology of employment arrangements

\begin{tabular}{llll}
\hline Type of contract & $\begin{array}{l}\text { Guaranteed } \\
\text { hours? }\end{array}$ & $\begin{array}{l}\text { Required to be } \\
\text { available for work? }\end{array}$ & $\begin{array}{l}\text { Guaranteed } \\
\text { income? }\end{array}$ \\
\hline Zero hours contract & No & Yes & $\begin{array}{l}\text { Compensation based } \\
\text { on a legal formula }\end{array}$ \\
\hline If and When contract & No & No & No \\
\hline $\begin{array}{l}\text { Hybrid If and When } \\
\text { type contract }\end{array}$ & $\begin{array}{l}\text { Yes for minimum } \\
\text { hours only }\end{array}$ & $\begin{array}{l}\text { Yes for minimum hours. } \\
\text { No for additional hours }\end{array}$ & $\begin{array}{l}\text { Yes for minimum } \\
\text { Hours }\end{array}$ \\
\hline $\begin{array}{l}\text { Regular full-time and } \\
\text { part-time employment contract }\end{array}$ & Yes & Yes & Yes \\
\hline
\end{tabular}

Source: O'Sullivan et al. 2015

Regardless of the type of contract workers are employed on, the negative impact is the same according to interviewees. Union officials and NGO representatives indicated the involuntary nature of such work for the majority of those employed on such contracts. The negative impact and involuntary nature of these contracts was also highlighted in a major industrial dispute in the retail sector in 2015 calling for a ban on such contracts (Mandate 2017). The most significant negative impact on employees of 'If and When' or hybrid contracts was described by the retail trade union Mandate as 'lack of control over their working lives'. While pay was a concern, security and stability of hours were also considered important issues. If hours remain unguaranteed or variable, then even when wage increases are secured, employees cannot predict earnings. The lack of predictability and certainty can impact on many aspects of employees' lives and can lead to stress due to the inability to make any financial commitments from week to week. Employees are often unable to access credit (e.g., for mortgage applications), as assessments are based on guaranteed contracted hours only even where employees may normally work in excess of those hours. Employees may be willing and available to work more hours but may suffer underemployment if hours are not available or employers choose to allocate hours across larger numbers of employees rather than increasing hours of existing employees. Even where low hour or 'If and When' contracts are chosen by employees, they are dependent on the goodwill of management to schedule hours to suit employees' needs. Employees may get 'trapped' in low-paid jobs where career planning is very difficult. They may not have pension coverage, so the negative effects of these contracts continue through their lifecycle, particularly where they are not transient in these jobs. The NWCI also noted that for women, variable hours inhibit their ability to take up extra work or to upskill and so they become trapped in a cycle of poverty.

Analysis of the QNHS data provided insufficient information on the extent of zero hours work in Ireland. The QNHS provides a wide range of data on those at work, including working hours, economic sectors, employment characteristics, and demographics. At present, however, it does not use any measures or questions on employment contracts including zero hour contracts. While the QNHS does not link working hours to types of employment contracts, the data indicate that $5.3 \%(84,848)$ of employees in Ireland in 2014 reported having 'constantly variable working hours'. These are employees who cannot estimate their usual hours of work because hours worked vary 
considerably from week to week or from month to month. This is the closest measure available to gauge the proportion of the workforce engaged in zero hours work. A limitation of this measure however is that it may also include persons not engaged in zero hours work. While zero hours work is often promoted as 'student work', the data show that students account for a minority of all those working part-time and variable parttime hours, at $15 \%$ and $20 \%$, respectively. Without more accurate data on the types of contracts these workers hold, these figures may be an overestimate or underestimate of the number of employees engaged in zero hours work. Nevertheless, combined with the data from the qualitative research, there are indications of considerable variability and flexibility in the Irish labor market and evidence of zero hours work in the form of 'If and When' contracts and hybrid contracts. A key finding of this study is that a number of questions should be included in future national surveys to measure the phenomenon of nonguaranteed hours of work. This is because crafting a single direct question measuring whether employees work under such contracts would be unlikely to provide an accurate picture of the range of employment arrangements identified (see Table 1).

\section{Discussion and Conclusion}

This paper set out to examine the issues with defining and regulating zero hours work. Until our recent study, an external observer would most likely have surmised that zero hours work is not problematic in Ireland given the regulation specified in the working time legislation. Reflecting on the OWTA, our findings show that rather than adequately addressing the issue of zero hours work, it was constructed in a narrow fashion and did not prevent or adequately regulate the full spectrum of zero hours arrangements. The findings show how the legislative framework has significant limitations in addressing issues around zero hours work. Our findings reflect suggestions by Adams et al. (2015:2) that the discourse surrounding zero hours contracts is fundamentally flawed, as it is predicated on 'an unspoken assumption that there is clarity and coherence in the notion of 'the' Zero-Hours Contract as a specific phenomenon in employment law, and in the labor market more broadly, and that it could - and should - therefore be regulated as such'. Our findings show it is relatively easy for employers to circumvent the provisions of the existing legislation by including clauses that do not require the employee to make themselves available for work. While workers may not be contractually obliged to be available for work information from trade union representatives and NGOs point to the reality for many 'If and When' workers of having to accept any hours offered. This was said to be mainly due to the need to earn additional income and the fear that if hours were refused employers would not offer hours again to that worker. Thus, the reality of 'If and When' and hybrid contracts for workers is essentially the same as zero hours contracts. The difference is that such workers are provided with no protection or compensation from the existing legislation. In fact, the way in which an 'If and When' contract is phrased serves to act further to the detriment of the worker by excluding the requirement of mutuality of obligation. The result is that 'If and When' workers remain in a decidedly legal 'grey area' with regard to their employment status and so are afforded little protection from the range of existing protective employment legislation even beyond working time such as unfair dismissals and redundancy. Thus, the regulation of zero hours work in Ireland requires a more nuanced approach. 
We noted earlier that the biggest challenges for researchers and policy makers were gaining reliable data on the number of workers employed in particular types of precarious employment and sufficiently regulating such work to protect workers and employers without inhibiting labor market flexibility. This study has sought to address these challenges by highlighting the gaps in the current national labor force data that have heretofore masked the true extent of zero hours work in the Irish labor market. It has also drawn attention to the inadequacies of the current legislation as a means of regulating such work to protect workers. As a result of the findings of the report on which this paper is based, discussions are currently underway in the Irish parliament on what changes might be made to better regulate the breadth of zero hours arrangements operating in the Irish labor market. These include provisions to provide more clarity to workers on their terms and conditions of employment from an early stage and placing workers on a 'band' of hours after they have regularly worked those hours for a certain period of time.

Earlier we asked, 'what do we mean when we talk about zero hours contracts? A key contribution of this research is that it demonstrates how difficult it is to define and quantify precarious work in the form of zero hours contracts. Even within a single country, there are three distinct forms of zero hours work, each with varying levels of protection from existing employment regulation. This was only possible through qualitative research methods, which provided important insights into the reality of workers' employment situations regarding working hours. A key issue that emerged from the interviews is the different interpretations various stakeholders hold of the same concept. Employer groups view 'If and When' work in a positive light as flexible working. In general, employer organizations believed that people working 'If and When' hours do so as a lifestyle choice and highlight the flexibility it offers certain segments of the labor market particularly women and younger people.

In the views of employee representatives and a number of NGOs, however, interpretation of the term zero hours contract is much wider in scope. Zero hours work (often referred to as zero hours contracts) has become synonymous with precarious, nonguaranteed hours of work and includes zero hours contracts, 'If and When' contracts and hybrid contracts as outlined in Table 1. For these stakeholders, all of these work arrangements are considered precarious work. The negative impact on employees stems from uncertainty and unpredictability of hours resulting in low income, limited social benefits and statutory entitlements, negative psychological effects, and transfer of risk from employer to employee. This conforms to the definitions of precarity identifiable in the literature (Kalleberg 2009, 2011, 2012; Olsthoorn 2014; Vosko 2010). One of the key lessons learned is that zero hours contracts (as legislatively defined) are only one form of a spectrum of precarious work. The policy implications of the findings are that consideration should be given to other forms of regulation besides legislation. Stakeholders have emphasized the importance of allowing employers and workers adapt working time arrangements to the circumstances of their particular industry or organization where collective bargaining may be a more effective mechanism for regulating zero hours work. Collective bargaining in other countries regulates nonstandard work generally by limiting the extent of nonstandard contracts and providing for equal pay and treatment for nonstandard workers. Multiemployer collective bargaining is common in European countries at inter-sectoral and sectoral levels. Sectoral-level agreements feature in France, Austria, Portugal, Finland, Slovenia, Sweden, the Netherlands, Italy, Norway, Germany, Cyprus, and Luxembourg (Adams \& Deakin 2014; Fulton 
2013). However, the role of collective bargaining in Ireland as with other European countries has declined significantly over the past few decades, as a result of neoliberal policies and it is unlikely that this will be reversed. The challenge remains for the Irish government then to find a way of regulating zero hours work in an LME that does not curtail labor market flexibility. Challenges also persist for those representing the interests of precarious workers to persevere in their campaigns for quality of work. Future ongoing research regarding the outcomes of both these challenges is critical.

Workers in Nordic countries are undoubtedly currently better protected against the negative impacts of zero hours and other forms of precarious work given the protections derived from the flexicurity model and other elements typical of CMEs. This paper did not set out to compare precarious work across Nordic countries. It may however provide insights for those that wish to undertake such a task and a number of points can be made. Precarious work is becoming an issue of concern in Nordic countries. The level of 'zero hours work' in Ireland based on the estimate of $5.3 \%$ of workers who work 'constantly variable hours' (the nearest estimate currently available) is close to the level of zero hours contracts in Finland, for example. To the best of our knowledge, Finland is currently the only Nordic country with statistical evidence of zero hours contracts. According to Statistics Finland in 2014, 83,000 employees (or 4\%) of all employees were employed on a zero hours contract (Parnanen 2017). Although students account for around one-third of this group and for these workers zero hours contracts are not considered to be problematic, there are a substantial minority $(25 \%)$ whose main activity is employment. Of this group, the main reason cited for working part-time (on a zero hours contract) is lack of availability of full-time employment and the majority are underemployed, that is, would like to have more hours work (Parnanen 2017). The threat that zero hours contracts present to workers in Finland became clear when a citizen's initiative (Operaatio vakiduuni) to legally ban such work was aimed at the Finnish parliament in January 2015. This however was subsequently rejected with the government instead limiting the use of zero hours contracts rather than an outright ban (Savolainen 2017).

Nielsen et al. (2017) in their study of precarity among young Danish workers note that internationally, the Nordic Model is often pointed out as a solution to the challenges facing workers and labor markets globally. The diffusion and impact of precarious employment is cushioned somewhat by social security measures and the flexicurity model. However, ignoring developments in precarious work and treating them as exceptions to the rule within the Nordic model may be dangerous. Again, Ireland is a useful case in point. Traditionally, multinational companies (MNCs), mostly of US country of origin, locating in Ireland between the 1960s and 1980s largely conformed to the prevailing institutional environment by recognizing trade unions and engaging in collective bargaining. There were a small number of MNCs who chose not to engage in collective bargaining, but these cases were seen as the exception and not the rule. However, over time, these cases paved the way for later and larger nonunion investments with the result that nonunion status became the norm rather than the exception, among inward investing MNCs (Gunnigle et al. 2009). Similarly, the fall in the system of centralized collective bargaining in 2009 in Ireland, which had been in place since the late 1980s, was seen as a consequence of the weak institutional structures on which the system was built and when pressure was applied (largely resulting from the global financial crisis), the institution of centralized collective bargaining fell apart (McDonough \& Dundon 2010).

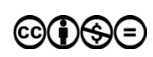


Developing institutional analysis further, Edwards et al. (2016) noted that much of the literature focuses on institutions as constraints on employment practices, that is, because a country has a particular institutional environment (e.g., a CME), organizations and management are constrained to behave in a certain way. However, in explaining the unexpected high incidence of forced distribution in performance appraisal systems in some Nordic countries (the VoC framework would suggest that this practice would not be prevalent in CMEs), Edwards et al. (2016) noted that institutions may not merely act as constraints but rather should be seen as facilitating and perhaps promoting certain practices. In this case, the flexicurity model was seen as promoting the uptake of an employment practice characteristic of an LME. A key lesson is that even within countries that are considered CMEs institutions may not do as we expect (Edwards et al. 2016) or that they cannot change (Streeck 2009). Because the Nordic flexicurity model provides an important 'safety net' for workers, this arguably may inadvertently incentivize employers to increase their use of zero hours and other forms of precarious work. Currently, this appears to be confined to very small numbers of marginalized groups of workers (particularly migrants) in weakly organized sectors in the Nordic countries.

However, falling unionization can create employer opportunities for a lowering of working conditions and incentivize employers to break from employer organizations and collective bargaining increasing the use of insecure contracts. As Thelen (2012:9) notes, 'when union density and membership in employer associations is concentrated in the public sector and manufacturing, and is in decline elsewhere, collective bargaining institutions will erode as employment shifts to the service sector'. This can threaten the institutional structures designed to protect workers and put pressure on delivery of the 'security' element at the expense of (employer's) flexibility. Already, Denmark, for example, has seen some controversial labor market reform (Dagpengereform) and tightening of regulations, which were 'criticized for reducing the security element of the flexicurity model' (Rasmussen et al. 2016). Liberalization, Europeanization, and the expanding global economy will no doubt continue to challenge the Nordic IR models increasing pressure on employers to adopt practices typical of LMEs (such as zero hours work) and institutions to facilitate this. Thus, research on precarious work in the Nordic countries is just as important and a concern for workers, trade unions, academics, and policy makers as in LMEs such as Ireland. The findings of this study provide important insights for this research.

This article also makes an important methodological contribution to research on precarious work. The findings show that relying solely on national statistics to capture the extent of the problem of precarious work may be insufficient in reflecting the reality of workers' situations. As new forms of precarious work are emerging, it is useful to examine other methods of researching different forms precarious work. Qualitative research methods such as interviews with informed stakeholders that formed a critical component of this study should not be discounted by those examining precarious work and working hours. These can provide important nuanced insights into the nature and type of work arrangements that may not be captured by data on working hours. Likewise, case studies and documentation of individual workers' experiences can also help to shed light on the reality of the impact of precarious work on workers' lives. Qualitative research can then serve to inform the types of questions that should be asked in national labor force surveys in order to gain an accurate picture of the extent of different work arrangements in order, for example, to fully capture the spectrum of zero 
hours work. This is currently the case in Ireland whereby the recommendations of the report on which this paper is based include suggestions for questions to be included in future national surveys to measure the phenomenon of nonguaranteed hours of work. It is recommended that these questions have a broader scope around hours of work than simply the number of hours usually worked, including the variability of hours, whether hours are guaranteed and the type of employment contract a worker believes they have (see O'Sullivan et al. 2015). This would help to more accurately quantify the true extent of zero hours work.

Concerns around zero hours work in Ireland were evident 20 years ago when trade unions pushed for provisions in working time legislation to deal with such work at a time when Ireland's institutional structures were more similar to CMEs. Over time, those structures have gradually eroded. The collapse of social partnership, declines in union density and erosion of collective bargaining coverage has meant that Ireland is now more typical of an LME where zero hours work is primarily regulated through legislation. Our research shows the inadequacies of legislation in regulating zero hours work given the nuanced differences that forms of zero hours work can take. Thus, employers are facilitated in circumventing regulations and problems with zero hours work are emerging for workers as a result of neoliberal policies, employer-oriented flexibility, and weak worker protection. In Nordic countries, the majority of workers are currently protected by strong levels of social dialogue, high levels of unionization, and coverage of collective bargaining. Thus, zero hours and other forms of precarious work appear to be less problematic - for now. Given the threats to the Nordic model of increasing liberalization and the emergence of precarious work among marginalized groups in certain sectors, it is critically important that policy makers, trade unions, and indeed workers do not become complacent. As well as organizing insecure workers, it is crucial to ensure that elements of the IR models such as collective bargaining, welfare support, and stable employer organizations are protected. How this will be done is a significant challenge and one which future research should pay attention to.

\section{Acknowledgement}

The authors received funding from the Department of Jobs, Enterprise and Innovation for a study on zero hours contracts.

\section{References}

Adams, A., Freedland, M. and Prassl J. (2015). The Zero Hours Contract: Regulating Casual Work or Legitimising Precarity? University of Oxford Legal Research Paper Series, Paper No. 00/2015.

Adams, Z. and Deakin, S. (2014). Reregulating Zero Hours Contracts, Liverpool: The Institute of Employment Rights.

Allmendinger, J., Hipp, L. and Stuth, S. (2013). 'Atypical Employment in Europe 1996-2011' Discussion Paper No. P 2013-003, Berlin, WZB.

Baccaro, L. and Howell, C. (2011). 'A Common Neoliberal Trajectory: The Transformation of Industrial Relations in Advanced Capitalism', Politics \& Society 39(4): 521-563. doi: https://doi.org/10.1177/0032329211420082. 
Barnard, C. (2014). 'Non Standard Employment; What Can the EU Do?' Keynote paper, European Labor Law Network. 7th Annual Legal Seminar, New Forms of Employment and EU law, 27-28 November, The Hague, Netherlands.

Berglund, T., Håkansson, K., Isidorsson, T. and Alfonsson, J. (2017). 'Temporary Employment and the Future of the Labor Market', Nordic Journal of Working Life Studies 7(2): 27-48. doi: https://doi.org/10.18291/njwls.v7i2.81523.

Blanchflower, D., Costa, R. and Machin, S. (2017). The Return of Falling Real Wages. Working Paper, LSE Centre for Economic Performance, London.

Brinkley, I. (2013). 'Flexibility or insecurity? Exploring the rise in zero hours contracts', London: The Work Foundation.

Broughton, A., Green, M., Rickard, C., et al. (2016). Precarious Employment in Europe: Patterns, Trends and Policy Strategies, Brussels: European Parliament.

Burgess, J., Connell, J. and Winterton, J. (2013). 'Vulnerable workers, precarious work and the role of trade unions and HRM'. The International Journal of Human Resource Management 24(22): 4083-4093. Doi: https://doi.org/10.1080/09585192.2013.845420.

Cerny, P. G., Menz, G. and Soederberg, S. (2005). 'Different Roads to Globalization: Neoliberalism, the Competition State, and Politics in a More Open World', in S. Soederberg, G. Menz and P. G. Cerny (eds), Internalizing Globalization: The Rise of Neoliberalism and the Decline of National Varieties of Capitalism, Basingstoke: Palgrave Macmillan. doi: https://doi.org/10.1057/9780230524439 1.

Chartered Institute of Personnel and Development (CIPD) (2013). Zero Hour Contracts: Myth and Reality, London: CIPD.

Commission of the European Communities (2006). Green paper Modernising Labor Law to Meet the Challenges of the 21st Century. Discussion Paper No. 1169 P 2013-003, Berlin, WZB.

Edwards, T, Sanchez-Mangas, R., Jalette, P., Lavelle, J. \& Minbaeva, D. (2016). 'Global standardization or national differentiation of HRM practices in multinational companies? A comparison of multinationals in five countries', Journal of International Business Studies, 47(8): 997-1021. doi: https://doi.org/10.1057/s41267-016-0003-6.

Eurofound (2015). New forms of employment, Publications Office of the European Union, Luxembourg. Available at: www.eurofound.europa.eu/sites/default/files/ef publication/ field ef document/ef1461en.pdf.

Fleckenstein, T. and Soohyun, C. L. (2017). 'The politics of labor market reform in coordinated welfare capitalism: comparing Sweden, Germany, and South Korea', World Politics 69(1): 144-183. doi: https://doi.org/10.1017/s0043887116000228.

Fulton, L. (2013). Worker Representation in Europe, Labor Research Department and ETUI.

Gunnigle, P., Lavelle, J. and McDonnell, A. (2009). 'Subtle but deadly? Union avoidance through 'double breasting' among multinational companies', Advances in Industrial and LaborRelations16(1):51-74.doi:https://doi.org/10.1108/s0742-6186(2009)0000016006.

Håkansson, K., Isidorsson, T. and Kantellius, H. (2012). Temporary agency work as a means of achieving flexicurity? Nordic Journal of Working Life Studies 2(4): 153-169. doi: https://doi.org/10.19154/njwls.v2i4.2309.

Hall, P. A. and Soskice, D. (2001). Varieties of Capitalism: The Institutional Foundations of Comparative Advantage, Oxford: Oxford University Press.

Hassel, A. (1999). The erosion of the German system of industrial relations, British Journal of Industrial Relations 37(3): 483-505. Doi: https://doi.org/10.1111/1467-8543.00138.

Hassel, A. (2002). The erosion continues: Reply, British Journal of Industrial Relations 40(2): 309-317. doi: https://doi.org/10.1111/1467-8543.00234.

Heyes, J., Lewis, P. and Clark, I. (2012). Varieties of capitalism, neoliberalism and the economic crisis of 2008-?', Industrial Relations Journal 43(3): 222-241. Doi: https://doi. org/10.1111/j.1468-2338.2012.00669.x. 
Howell, C. and Givan, R. K. (2011). 'Rethinking Institutions and Institutional Change in European Industrial Relations', British Journal of Industrial Relations, 49(2): 231-255. Doi: https://doi.org/10.1111/j.1467-8543.2010.00846.x.

ILO (International Labor Organization) (2012). From Precarious Work to Decent Work: Outcome Document to the Workers' Symposium on Policies and Regulations to Combat Precarious Employment, Geneva: ILO.

Ilsøe, A. (2016) 'From living wage to living hours - the Nordic version of the working poor', Labor and Industry 26(1): 40-57. doi: https://doi.org/10.1080/10301763.2016.1152534.

Kalleberg, A. L. (2009). 'Precarious work, insecure workers: employment relations in transition', American Sociological Review 74(1): 1-22. doi: https://doi.org/10.1177/00031 2240907400101.

Kalleberg, A. L. (2011). Good jobs, bad jobs: The rise of polarized and precarious employment systems in the United States, 1970s to 2000s, New York, NY: Russell Sage Foundation.

Kalleberg, A. L. (2012). 'Job quality and precarious work: clarifications, controversies, and challenges', Work and Occupations 39: 427-448. doi: https://doi.org/10.1177/ 0730888412460533.

Kaufman, B. (2011). Comparative employment relations: institutional and neo-institutional theories in M. Barry and A. Wilkinson (Eds) Research Handbook of Comparative Employment Relations, Cheltenham, UK, Edward Elgar pp. 25-55. doi: https://doi.org/10.4 337/9780857936318.00008.

Kinderman, D. (2017). 'Challenging varieties of capitalism's account of business interests: Neoliberal think-tanks, discourse as a power resource and employers' quest for liberalization in Germany and Sweden', Socio-Economic Review 15(3): 587-613. doi: https:// doi.org/10.1093/ser/mww040.

Lea, J. (2013). 'From denizen to citizen and back: governing the precariat through crime', Criminal Justice Matters 93(1): 4-5. doi: https://doi.org/10.1080/09627251.2013.833751.

Mandate (2017). 'A big week for the Decency for Dunnes Workers campaign', Mandate Trade Union. Available at: https://dunnesworkers.com/2017/05/08/a-big-week-for-thedecency-for-dunnes-workers-campaign/.

McCann, D. (2014). 'Equality through precarious work regulation: lessons from the domestic work debates in defence of the Standard Employment Relationship', International Journal of Law in Context 10(4): 507-521. doi: https://doi.org/10.1017/s1744552314000251.

McDonough, T. and Dundon, T. (2010). Thatcherism delayed? The Irish crisis and paradox of social partnership, Industrial Relations Journal 41(6): 544-562. doi: https://doi. org/10.1111/j.1468-2338.2010.00585.x.

McMahon, J., O’Sullivan, M., Turner, T., Ryan, L., Lavelle, J., Murphy, C., O’Brien, M. and Gunnigle, P (2017). 'Zero Hours Work and the Role of the Law in Ireland' In: The New Foundations of Labor Law, Frankfurt, Germany: Peter Lang.

Nielsen, M. L., Görlich, A., Grytnes, R. and Dyreborg, J. (2017). 'Without a safety net: precarization among young Danish employees', Nordic Journal of Working Life Studies 7(3): 3-22. doi: https://doi.org/10.18291/njwls.v7i3.97094.

Office for National Statistics (ONS) (2015). Analysis of Employee Contracts that do not Guarantee a Minimum Number of Hours. Available at: https://webarchive.nationalarchives.gov.uk/20160106043913/http://www.ons.gov.uk/ons/dcp171776 415332.pdf.

Ollus, N. (2016) 'Forced flexibility and exploitation: experiences of migrant workers in the cleaning industry', Nordic Journal of Working Life Studies 6(1): 25-45. doi: https://doi. org/10.19154/njwls.v6i1.4908.

Olsthoorn, M. (2014). 'Measuring precarious employment: a proposal for two indicators of precarious employment based on set-theory and tested with Dutch labor market-data', Social Indicators Research 119(1): 421-441. doi: https://doi.org/10.1007/s11205-0130480-y. 
O’Sullivan, M., Turner, T., McMahon, J., Ryan, L., Lavelle, J., Murphy, C., O’Brien, M and Gunnigle, P. (2015). A Study of the Prevalence of Zero Hours Contracts among Irish Employers and its Impact on Employees, Dublin: Department of Jobs, Enterprise and Innovation, November. Available at: https://dbei.gov.ie/en/Publications/Publication-files/ Study-on-the-Prevalence-of-Zero-Hours-Contracts.pdf.

O’Sullivan, M., Turner, T., Lavelle, J., McMahon, J. Murphy, C., Ryan, L., Gunnigle, P. and O'Brien, M. (2017). 'The role of the state in shaping zero hours work in an atypical liberal market economy', Economic and Industrial Democracy 1-20. doi: https://doi. org $/ 10.1177 / 0143831 \times 17735181$.

Parnanen, A. (2017). Statistics Finland: What LFS Tells About Changes in the Labor Markets - Case of Finland, LFS Workshop, Copenhagen, Denmark, 17 April. Produced with the assistance of the SEEurope Network. Available at: [http://www.workerparticipation.eu/ National-Industrial-Relations].

Rasmussen, S., Refslund, B., Sørensen, O. H., and Larsen, T. P. (2016). Reducing Precarious Work in Europe Through Social Dialogue: The Case of Denmark, Report for the European Commission, Aalborg University and Copenhagen University. Available at: http:// www.research.mbs.ac.uk/ewerc/Portals/0/Documents/Denmark-final-report.pdf.

Savolainen, A. (2017). Finland: Latest working life developments - Q4 2017, European Observatory of Working Life, Eurofound: Dublin. Available at: https://www.eurofound.europa.eu/publications/article/2018/finland-latest-working-life-developments-q4-2017.

Standing, G. (2014). A Precariat Charter: From Denizens to Citizens, London: Bloomsbury, Available at: https://doi.org/10.5040/9781472510631.

Streeck, W. (2009). Re-Forming Capitalism: Institutional Change in the German Political Economy, Oxford: Oxford University Press.

Thelen, K. (2012). Varieties of Capitalism: Trajectories of Liberalization and the New Politics of Social Solidarity, Florence: Max Weber Programme, MWP - LS 2012/03.

Treu, T. (1992). 'Labor flexibility in Europe', International Labor Review 131(4-5): 497-513.

Turner. B. S. (2016). 'We are all denizens now: on the erosion of citizenship', Citizenship Studies 20(6-7): 679-692. doi: https://doi.org/10.1080/13621025.2016.1191432.

Vosko, L. (2010). Managing the Margins: Gender, Citizenship, and the International Regulation of Precarious Employment, Oxford, UK: Oxford University Press. 